\title{
The kingdom of God and modern society
}

\author{
J.A. de Jong \\ Department of Historical Theology \\ Calvin Theological Seminary \\ GRAND RAPIDS \\ USA \\ E mail: dejj@calvin.edu
}

\begin{abstract}
The kingdom of God and modern society

The kingdom of God implies God's rule in the regenerated heart. Consideration of the kingdom and modern society should be understood ecclesiologically. Herman Ridderbos' notion of the relation of church and kingdom (sign, first-fruits, and instrument) is helpful, but must be applied in the context of nine realities of modern society. Corporate, modern discipleship is created when the church institute attends to all the features of its calling. This includes imparting biblical principles and giving general direction for modern social programmes and practices, but refraining from expressing itself on the specifics of complex programmes.
\end{abstract}

\section{Backdrop against which to reflect on the above- mentioned topic}

Identifying the presence of God's kingdom in our own time is bafflingly complex. Where is God at work, exercising his redemptive, restorative dominion in the cross of Jesus Christ? Perhaps discerning this is not our calling or responsibility and it is presumptuous of us to even raise the prospect of doing so. On the other hand, Paul instructs us to discern the times and Jesus directs us to read the signs of the times. We are taught to test the spirits of our age in order to know what is of God and what is not. The gospels teach us to watch and to pray. On the other hand, we are warned against chasing false messiahs and notified that even the Son of Man does not know the day and the hour of the coming of the Lord to judge the nations. What are we to make of this apparent New Testament ambivalence concerning the kingdom of God and modern society? We are at once compelled, drawn with a holy fascination into reflection on and identification of the kingdom, and on the other hand, we are warned about being speculative or definitive on the shape and timing of the kingdom. 
The complexity of the subject of the kingdom and modern society may be illustrated by Desmond Tutu's recent book on his work with the Truth and Reconciliation Commission, No Future Without Forgiveness (1999). It recounts an unprecedented political experiment in social restoration and healing. Upon reading it, one wonders whether the abolition of apartheid - was it of God or was it of man, the kingdom of light or the kingdom of darkness? Tutu observes that today scarcely no one in South African society affirms that they were supportive of the system, particularly as it has been exposed in recent years. If that is so, then all will agree today that God's hand was in those movements that militated against the system in the 1970s and the 1980s, and that his Spirit was leading Prime Minister F.W. de Klerk in the leadership he took in dismantling first klein apartheid, then the entire system. However, twenty or thirty years ago the matter seemed highly ambiguous. The threat of militant communism instilled political paranoia during the Cold War years. Black-on-black violence was spun by the media to suggest that destabilising the existing social order would land South Africa in a bloodbath of anarchy and in economic ruin. Maintaining racial boundaries through political policy then was, when the spectre of injustice was raised, countered with the observation that blacks enjoyed a higher standard of living, of medical care, and of education of anywhere in sub-Sahara Africa. If those opinions seem feeble and embarrassing today, they did not then. That is the point. South Africa found itself in a situation then similar to that of the United States when it was compelled to discern and affirm the will and the kingdom of God in the racial battles of the 1960s and in the throes of its early engagement in Vietnam. Discerning the kingdom amidst the complexities of modern society is imperative, but complicated. A heightened dimension of the complication, as Archbishop Tutu also notes, is that God's presence and work usually transcend our human divisions. Winnie Mandela's soccer club was an unprincipled mafia that lived by violence just as did the unprincipled units of the security forces. Acts of black endurance and faith were echoed by acts of white compassion and risk. The wheat and the tares grow together. The kingdoms of light and darkness contend on the same terrain.

These prefatory remarks on the complexity and ambiguity of the kingdom of God and modern society are the backdrop against which to reflect on the topic.

\section{Preliminaries}

When the relation of the kingdom and modern society is considered, some basic terms and connections must be clarified. 
- First, by the "kingdom" is understood the sovereign rule of God (re)asserted through his saving, renewing work in Jesus Christ as effectuated by the ministry of his Spirit and Word. The term is not used here in the sense of God's domain or territory, although he rules over all that He has made. The more dynamic, redemptive, synoptic sense of the term is intended.

- Second, the phrase "modern society" that follows has in mind the highly urbanised, technologised, intricately organised form of 21st century life derived substantially from Western spiritual, intellectual and scientific efforts. Using the term in this restricted sense reflects a bias against many contemporary societies that remain less touched by these influences.

- Third, one cannot speak meaningfully of the kingdom and modern society without introducing a third term, namely "the church". A welldeveloped ecclesiology will determine to a significant degree how one speaks about the kingdom and modern society. By the church is meant the people of God who corporately profess Christ as Lord and Saviour and who incarnate aspects of the kingdom in their lives of service to the King.

The saving, renewing rule of God in Christ occurs most explicitly and consistently among those whose hearts the Spirit has renewed and whose discipleship He is shaping in response to the gospel. This places the church in a unique, privileged, and strategic position with respect to the kingdom of God. Herman Ridderbos (1962) remains uncommonly lucid and helpful in understanding the relationship between church and kingdom. He indicates that the connection between the church and the kingdom is complex and manifold. The church is the first-fruits of the kingdom, the sign of the kingdom, and the instrument of the kingdom in society. These connections between church and kingdom function presuppositionally in what follows.

This is not to argue, however, that this ministry of Spirit and Word is confined exclusively to the church as God's people, much less to the church in its organised, institutional manifestation. God's saving, renewing rule does occur beyond the church and sometimes in spite of the church. The Spirit moves where it wills, and God speaks not only in his special revelation, but also in his general revelation and even conveys a message of grace and reconciliation and hope that turns people to his ways apart from the church and its witness. Whether this rule is ultimately redemptive, must be left to his secret councils. This acknowledgement, which the orthodox and confessional church and its theologians have not always readily made, has profound implications for the relation- 
ship between the kingdom and modern society. The kingdom is larger than the church, and it sometimes comes despite resistance from the church. The church, under its own, special guidance by the Spirit and the Word, must always be alert to what the Lord is saying and doing in modern society to establish his kingdom.

\section{Features of modern society}

Listing and briefly characterising some features of modern society are a helpful background for understanding the connection between the kingdom and modern society. These features are forces calling citizens of the kingdom to prophetic discernment and new, more sophisticated forms of obedience. One of the greatest challenges faced by the church is to articulate a contemporary kingdom ethic that honestly addresses these features of modern society.

\section{- Globalisation}

The first feature is globalisation. The world is interdependent in ways undreamed of just a generation ago. Multi-national corporations, telecommunications, rapid and relatively inexpensive travel, shared cultural products from Coca Cola to Sushi bind people to one another tightly. One economy impacts another. Political turmoil in Indonesia drives down the Singapore stock market. The policies of OPEC determine vacation plans in Europe and North America. Languages are seasoned with imported terms. But with this increased interdependence, have people produced a better, higher culture? Have they devised forms of accountability and systems of justice adequate for this new reality? Are the needs and rights of all peoples equally recognised and honoured? What is kingdom responsibility in the face of globalisation?

\section{- Pluralism}

The second feature of modern society is pluralism. In most modern societies a plurality of value systems and faiths is now accepted. The time is past when a modern society is dominated by one religion. Others cringe when militant Catholics and combative Protestants bomb one anothers' homes and businesses in Northern Ireland. They wince when Moslems and Christians slaughter one another and burn each others' houses of worship. The world employs sanctions and turns up the political rhetoric when the People's Republic of China crushes dissident students with tanks in Tianimin Square. But has it adequately articulated a principled pluralism that respects people of all faiths who contribute to the common good? Can it even define "the common good" in a religiously and ethically pluralistic society? How far can tolerance stretch before community is fractured and the foundations of society crumble? In 
another vein, have the children of the kingdom lost their zeal for the lost in a pluralised society? Are they complacent, lukewarm or indifferent toward evangelism? What shape should be given to discipleship and Christian life in modern times? Martin Marty once asked, "Why cannot the committed be civil and the civil be committed?" The pluralism of modern society poses issues that cry for kingdom illumination.

\section{- Secularisation}

A third feature of modern society is secularisation. In a secularised context life shrinks to the issues of this age. The philosophy of postmodernity has captured the campuses of major universities. Language means what I want it to mean, not what it says. Truth is relative. The standard of morality is what pleasures me as long as it does no harm to another. The meaning and purpose of life are to achieve financial security, for this ensures that necessities are provided and that luxuries can be enjoyed. Politically modern society has privitised faith and alienated it from public discourse. Educationally modern society regards faith-seeking understanding as obscurantism and scientifically irrelevant. Courts have systematically removed prayer from public schools, banned manger scenes from municipal buildings, and blocked the display of the ten commandments and pictures of Jesus in classrooms. While these initiatives have been taken in the name of protecting religious pluralism, they have the effect of secularising public discourse and are interpreted by some as a repression of the Christian faith. How can the church counteract secularisation? Does it have the will to do so? Has it articulated for today what it means to seek the kingdom and its righteousness in all areas of life? Are Christians going to be content with Tertullian's position, "What has Jerusalem to do with Athens", or will we give space again to the Lord of lord's and King of kings in modern society? If so, how? Secularisation is not congenial to the kingdom.

\section{- Social reconfiguration}

Social reconfiguration is a fourth feature of modern society. It may be the most fundamental change witnessed in the last generation, more defining of human life than the space age, the atomic age, or the computer age. In the last fifty years all human relationships have been subjected to scrutiny and redefinition. Following World War II colonial holdings gained political independence and claimed their place in world forums. The relationship between races was redefined through the civil rights movement in the United States and the dismantling of apartheid in South Africa. Women's liberation brought new attitudes and expectations to marriage and to the workplace. Society is preoccupied with defining legally and socially a new acceptance for homosexual persons. In Western jurisprudence children are accorded attention and protection which 
were unknown a generation ago and which have affected the parentchild relationship. The ecology movement has redefined humanity's relationship to the environment and the ethic of earth-keeping has emerged. The animal rights movement has caused people to take a fresh look at the relationship of humans and animals. In short, the world has witnessed and is continuing to witness a great democratising of all human relationships on a scale that is unmatched since the beginning of recorded history. Such massive social reconfiguration has shattered old assumptions and redefined human values. Is this the dawn of the millennium? Has a brave new world of peace and justice for all begun? Is God's kingdom dawning with new power and glory? Or, are these developments his providential tolerance of a massive dislocation that will hurl humanity into social chaos? Or, do these social changes represent some of both?

\section{- Technologised communication}

A fifth feature of modern society is technologised communication. E-mail with attachments has become a preferred form of rapid communication. The fax machine is well on its way to obsolescence. Interactive video transmission is redefining education and business conferencing. Via satellites and cell phones one can be in instant contact with anyone anywhere who is similarly equipped. Digitalisation of photographs and the printed page today make whole libraries accessible globally via computer. Educational literature is already talking about the impact that the communication revolution will have on universities. Internet companies exist that specialise in resourcing schools for putting their courses on-line, where they can be accessed globally. Imagine the implications this has for resident campuses and for international student exchange programmes. Aside from the field of higher education, technologised communication has redefined inventory control, shipping procedures, filing systems, and personnel records in business. E-commerce is a burgeoning industry barely five years old. The quantity of current information on virtually any topic imaginable that is accessible on the information highway baffles the mind. Even greater marvels will appear shortly. But like many technological advances, all these marvels are being used for sinister as well as for constructive purposes. News stories of adults seducing children electronically, the largely unchecked global dissemination of pornographic materials, hacking into classified government records, theft by computer, and the intentional spawning of computer viruses - all these perversions show that the new technologies in communication are being enlisted in the cause of darkness as well as in the cause of light. How fervently the church should be praying, "Your kingdom come in and through modern communication technology; your will be done in this arena of modern society as it is done in heaven". Who 
is casting out the technological demons, like the Lord exorcised the possessed of his day and delivered them so that modern demoniacs sit at his feet clothed, cleansed, and in their right minds?

\section{- Wealth distribution}

The sixth feature of modern society is the sensitive subject of wealth distribution. The accumulation of wealth has been attributed to colonial and worker exploitation, birth into a privileged class, invention and ingenuity, hard work, thrift, good stewardship, and favourable markets. Whatever the causes, just or unjust, hard questions remain. Is it just that a fraction of the earth's population controls a disproportionate level of the world's wealth and consumes the lion's share of its resources? Do the claims of Canadian aboriginals, U.S. native Americans, and black Africans represent in any legitimate sense the sins of colonial fathers being visited upon their children of the present generation? Is the pope, by endorsing the "Jubilee 2000" initiative to forgive Third World debt, articulating the claims of the kingdom? Or is this well-intentioned effort fool's play that subverts just economic order and funnels yet more money into the secret Swiss accounts of corrupt world leaders? What programmes ought to be initiated among the disadvantaged to provide them with the resources and opportunities that will lift them beyond poverty and despair? In modern society the children of the kingdom may not give their destitute contemporaries economic stones for bread.

\section{- Concentration of political power}

A seventh feature is the concentration of political power in the modern world. The United States, a federated Europe, and an emerging Peoples' Republic of China represent such concentrations. But sophisticated systems of weapons' delivery and surveillance enable rogue nations to enforce their policies on others or to disrupt human affairs. Increasingly all governments have the capacity to gather and to retrieve detailed information about every aspect of citizens' lives and to regulate and to control societies. What enormous potential for good or evil political power holds today. Governments can promote peace and justice, or they can repress and dehumanise people. They have the resources to guarantee freedom and opportunity, or to enslave their populations. In this context, what does it mean to "render unto Caesar that which is Caesar's and to God that which is God's"? Does the church have an ethic of the kingdom that adequately addresses modern political realities? How involved should the church as institution become in rendering political opinions, assessing federal and local policies, speaking out against injustice, lobbying for its own legitimate rights, engaging in subversion if necessary, or risking its internal unity by speaking with a prophetic voice to the powers of this age? 


\section{- Revolution in genetics and health care}

The revolution in genetics and health care is an eighth feature of modern society. By means of the "genome project", medical science has created the potential to program people genetically so as to purge them of genetic defects, to improve health, and to prolong life. The implications of this advance are staggering. Genetic engineering, in vitero fertilisation, organ donations and transplants, the development every year of new drugs and antibiotics, the ability to prolong life, not to mention older advances like "the birth control pill", have imposed on modern society a baffling complexity of ethical questions. How are these signs and wonders to be interpreted and utilised? In kingdom perspective, is healing only for the privileged and the wealthy of the world? What is God's will? What priority must be given this problem in the entire scheme of things? Where is the army of young Mother Teresas needed to educate the healthy, to embrace the dying, to dispense the drugs that can arrest the advance of AIDS? If our Lord came, as he did, not to be served but to serve, and if to enter the kingdom is to follow him, as it is, can the church tolerate indifference or resignation on this urgent matter? The coming of the kingdom came with the healing of the sick and the raising of the dead. This must be proclaimed until the drug conglomerates, the relief agencies, and the governments of this age hear and respond.

\section{- Spiritual longing}

A final feature of the modern world is the enormous spiritual longing with which people live. Young people on university campuses readily converse about meaning and values. Seminaries are filled with secondcareer people compelled by the Spirit to leave often lucrative careers to train for a meaningful life of ministry. Muslim fundamentalists are redefining political dynamics in their zeal for Allah. Bookstores are crammed with New Age and occult titles. People yearn for spiritual authenticity in their marriages and their churches. The Christian book business has never flourished in North America as it does today. The Russian intelligentsia raised the issue of transcendent values as the fundamental need of their new order, and the Orthodox church there is flourishing. Christians in Asia, Africa, and Latin America now outnumber those in the West; their churches continue to grow, sometimes at astonishing rates, because they fill a deep spiritual emptiness. In the modern world the fields are white unto the harvest of the kingdom.

These nine features of the modern world are kingdom opportunities. Others could be added. They demonstrate that as modern society changes, and as the pace of that change accelerates, the problem of the kingdom and modern society becomes more complex and more urgent. 


\section{Challenges for the church}

How can God's kingdom come in this baffling complexity we have just outlined? How can his saving, renewing dominion in human hearts and over modern society occur? How will all of created reality, scarred and perverted by sin, be restored to the beauty and order that God intended? That is the fundamental question when we address the subject of the church and modern society.

\section{- The kingdom comes by grace}

The first and most important thing to emphasise here is that the kingdom comes by grace. It is a gift of God. The writer of Hebrews, speaking to a wavering and disillusioned group of Jewish Christians whose society made no room for them, even passionately worked to be rid of them, encourages them to faith. He urges them to remember those ancestral heroes of faith who longed for a better country but who were strangers and aliens on earth. Because they trusted in God, he "is not ashamed to be called their God, for he has prepared a city for them" (Hebrews 11: 16). Note well that God has a grand design in mind. He has prepared a city for the saints. It is predetermined. He is the architect of the new order. And that new order is already breaking into this old order. It comes on his timetable. It appears sometimes when we least expect it, so that we are "surprised by joy," to use C.S. Lewis's expression. And it comes by God's means, which is pre-eminently through the gift of his Son, our Lord Jesus Christ, into whose hands all authority on earth and in heaven has been delivered. Unless we begin with the conviction that the kingdom is a gift of grace, we will be doomed to despair rooted in our always unfulfilled and pathetically inadequate endeavours to create a new order.

\section{- The kingdom comes to and through those who profess Jesus as Lord}

The second point to make about how the kingdom relates to modern society is that it comes most consistently and most clearly, all things considered, to and through those who profess Jesus as Lord. I affirm this cautiously, hesitantly, and with qualification, because believers are also restoration projects in process. They are also at times instruments of the other kingdom. One of the great lapses in Dutch-Reformed memory is that we applied Abraham Kuyper's doctrine of the antithesis to Christian vs. non-Christian institutions and systems of thought, but forgot or muffled the biblical truth that it is also a principle at work in the believer's heart and mind and life. We as Christians compromise the kingdom in ourselves, which is why we often send such mixed signals to each other and to those around us. We are not yet what we should be; we are still walking the road of sanctification. But having registered this caveat, we 
affirm that in good Christians, strong and consistent believers, the kingdom comes to clearer and more consistent expression than in those who do not think and live under the Lordship of Jesus Christ.

\section{- Modern discipleship}

The third observation to be made about how the kingdom interfaces with modern society is that it requires modern discipleship. Modern discipleship certainly includes faithful practice of the time-proven spiritual disciplines: reading Scripture and meditation on the Word, heartfelt personal and corporate prayer, public worship, fellowship with God's people, cultivation of the fruit of the Spirit, self-examination, self-denial, sacrificial service of others, telling others of the hope that is within us, sharing the gospel and calling others to the Lord, honest confession of sin and failing, the pursuit of reconciliation, generosity, stewardship, and so on. But modern discipleship requires more. It requires that we be as thoroughly informed on the forces of modern society as we possibly can. Christ masters the modern world in part through our mastery of the issues our world faces. We must read and discuss the most thoughtful insights on them, from all points of view. Then we must charitably and lucidly offer our biblically sensitised, believing opinion, critique, and solutions. Modern discipleship means that we must devise strategic approaches and programmes to convey and test our ideas. It means that we must enter, support, or even create the organisations and institutions that can influence and shape modern society as God would have human life lived. It also means that we must be open to revise and enhance our views because modern society produces new things at an accelerating rate of change. Responding faithfully to the call to modern discipleship is a sine qua non for the coming of the kingdom in and through modern society.

But who is equal to all this? Modern society is so vast and so complex. We must limit our involvements, focus our attention, select our issues. How can we be modern disciples? The answer is that we cannot - not alone, not as individuals.

\section{- Practising corporate discipleship}

So the fourth point I make is that the kingdom begins to emerge in modern society when modern discipleship comes to corporate expression. It has never been as imperative to practise corporate discipleship as it is today. Our times demand it. Our Lord expects it. Our contemporaries need it. Corporate modern discipleship must possess several qualities or characteristics to be effective. It requires sustained fellowship among Christian experts in specific arenas of modern life, their collective reflection on matters engaging their fields, intelligible and effective com- 
munication or dissemination of their contributions to the entire believing community, trust and respect for these contributions, achieving a wider Christian consensus on what these contributions imply for modern society, and the definition and mobilisation of strategies for affecting liferenewing changes in modern society.

\section{- Modern discipleship comes to expression in the church}

In the fifth place, corporate modern discipleship comes to expression in the church. This brings us into the thicket of Reformed ecclesiology, with its debates about the church as institute and the church as organism familiar to all of us. In mapping the terrain of the kingdom and modern society it is useful to engage a sampling of thinking of this matter.

A century ago, in 1901, Archibald Robertson delivered the Brampton Lectures on the kingdom of God. Robertson served as Anglican bishop of Exeter from 1903-1916, held principalships prior to that, and was a recognised expert on the thought of Athanasius. These eight lectures are substantially a review of the idea in the history of Christian thought. 1 Lectures I-III deal with the idea in Scripture: in the Old Testament, in the generation before Christ and in Paul and the synoptics, and in John and the rest of the New Testament. Lecture IV reviews the largely millennial interpretation dominant during the first four Christian centuries. Lecture $\mathrm{V}$ treats the two-fold Augustinian conception subsequently taken in divergent directions with equally unsatisfactory results. Lecture VI examines the institutionalised, papal interpretation, representing one Augustinian thread and allowing no sense of the kingdom outside the medieval church. Lecture VII handles the late medieval break-up of this understanding. Lecture VIII develops the more spiritualised Augustinian motif reflected in such theological constructs as that of "the church invisible" in Reformation and post-Reformation thought. Robertson frames his study against the two-fold background of the purpose of the government of the world in general, or God's providential control of all things, and the purpose of human lives specifically (Robertson, 1901:1-6). Both aspects are addressed in the biblical notion of the kingdom (Robertson, 1901:6).

The last twenty-five pages of the eighth lecture bring Robertson's survey into the neighbourhood of our theme. He summarises the thought that the church has always held that the kingdom is the "eternal reign of the Father, to be inaugurated by the second advent and the last judgment" an eternity of God's "perfect moral government". Also, Christians have always accepted that the kingdom is "within", where it governs heart and

1 See Robertson (1901). Louis Berkhof's The Kingdom of God: The Development of the Idea of the Kingdom, Especially Since the Eighteenth Century (1951) is a similar title dealing more pointedly with a limited period in the history of Christian thought. 
conscience and is marked by a new will and a new character that portend its full arrival. What is less universally accepted by believers is the interfacing of God's reign in their lives now, which all embrace, with its presence and manifestation in society or culture more widely (Robertson, 1901:364). Some leaders and Christian movements have stressed the kingdom as a corporate holiness distinguishing and separating the church from the world. Others have accented believers' collective rule or governing power over not just church members, but over "all the kingdoms and societies which exist among mankind" (Robertson, 1901: 365). Millennarians and medieval Catholic thinkers emphasised the latter, for example. But this emphasis failed, and Robertson favours Bishop Butler's moderate post-millennialism, which is expressed in his Analogy and articulates the vision of a virtuous society governed in all its manifestations by the good judgment of "Christian consciousness, progressively enlightened by the Holy Spirit" (Robertson, 1901:368-371, especially n. 1 on page 371). While the legislated, organisational manifestation of God's reign in history is acknowledged as important, it never achieves the higher ideal of his reign in human hearts, according to Robertson.

We can affirm Robertson's rejection of Christian socialism - or of the Social Gospel Movement in North America - as spiritually, religiously inadequate attempts at social amelioration. We identify with his emphasis on regeneration, on the pervasive but imperfect manifestation of the kingdom in modern society, on the calling of the church to realise the kingdom, and on the superiority of the eternal kingdom. But he does not address the matter of how the church in its organisational apparatus is an instrument of the kingdom. And he exhibits the Constantinian assumptions operative in the England of his day that the state and the Anglican Church were coterminus and spiritually synchronised.

H. Richard Niebuhr's classic, Christ and Culture (1951), deals with our topic of the kingdom and modern society. He describes and evaluates five sometimes conflicting and competing Christian answers to the issue of how the kingdom comes to expression in modern society. He hopes to bring a deeper mutual understanding and appreciation of these responses to the question of how Christ exercises his dominion in human society. All share the common conviction, says the author, "that Christ as living Lord is answering the question in the totality of history and life in a fashion which transcends the wisdom of all his interpreters yet employs their partial insights and their necessary conflicts" (Niebuhr, 1951:2). Their variation lies in the fact that different groups in the Christian tradition have different understandings of who Christ is. Medieval monastics and others stress Christ against culture, separate themselves from the world, and create a spiritual alternative. The Christ of culture answer says that Jesus evokes and affirms the highest human aspirations in 
society, and is represented by those who closely identified Christianity with Western civilisation. The next three profiles represent middling positions to the first two. The third interpretation endeavours to hold the first two in creative tension while affirming that as Lord Christ transcends and controls that tension to achieve his ends with society. Similarly, the fourth prototype is that of "Christ and culture in paradox", where believers answer to the authority of both even though they may be in apparent contradiction; Luther is the example Niebuhr cites. Finally, Augustine and the Reformed family represent the fifth position, namely the "Christ as transformer of culture"-interpretation of how the kingdom intersects with modern society. While contrived and admittedly limited, these characterisations are helpful in assessing how Christians have struggled to apprehend how the kingdom of God relates to the modern world. Niebuhr says, in the end, that each of them is an attempt to work out the conviction that Christ "is not only head of the church but redeemer of the world ... that the world of culture - man's achievement - exists within the world of grace - God's kingdom" (Niebuhr, 1951:256).

In addition to what Archibald Robertson and $\mathrm{H}$. Richard Niebuhr offer on our subject, we consider the fairly consistent position within Reformed Ecumenical Council circles that champions the Kuyperian distinction between church as institute and church as organism in addressing the relationship of the kingdom and the modern world. The literature is substantial, and is represented by the 1980 report, "The Church and Its Social Calling". 2 A decade after this report appeared, Paul Schrotenboer, former general secretary of the REC, claimed this important distinction as fundamental to the difference between REC ecumenicity and World Council of Churches ecumenicity. "The church, says the REC, should always perform its social and political functions in a manner that is in accordance with its particular nature" (Schrotenboer, 1989:17). He identifies a four-fold task for the church institute: 1) to preach the gospel and disciple people; 2) to equip and to mobilise the membership in Christ's mission; 3) to pray for the world; and 4) to engage in meaningful diakonia. But the church should not hesitate to articulate guiding principles of Scripture regarding the kingdom in its address to the modern world. But how specifically programmatic should the institutional church's voice be on social and political issues, Schrotenboer asks. Noting that the Dutch GKN adopted statements on abortion and nuclear energy, he reports that it was driven by intense reaction from its membership to

2 Various theme issues of Theological Forum, the REC publication on current topics reflects this perspective: "Contextualizing the Gospel" (XV(4):11-87); "Western Culture, Africa, and the Kingdom of God" (XVI(1):3-88); "Justice, Peace, and the Integrity of Creation" (XVII(3):10-89); "Indonesia and the Kingdom of God" (XVIII(3):8-90); "Group and Human Rights in South Africa" (XVIII(4):12-90). 
attempt a distinction between statements that "contribute to a discussion" and those functioning as a "testimony" (Schrotenboer, 1989:9). On the latter the GKN synod allowed no more than four dissenting votes to adopt a "testimony" as the church's position. He concludes from this review that the GKN has "no clear line between appropriate and inappropriate ecclesiastical statements on social and political issues" (Schrotenboer, 1989:19). He, however, appears to share this ambiguity when he concludes with a summary statement from the 1980 REC report:

The church is related to the world, as the latter exists in its alienation and rebellion against God, in a permanent tension of distance and concern, antithesis and involvement. This tension applies to the church both in its institutional form and as a fellowship of believers (Schrotenboer, 1989:20).

Schrotenboer's emphasis on the primary tasks of the institutional church is to be appreciated. So is his emphasis that as the people of God the church as organism is to be called, motivated, and engaged in all areas of human endeavour by its kingdom perspective and convictions. One wishes for more clarity and guidance from him on the limits of the institutional church's social and political pronouncements, despite his critique of the WCC for speaking too pointedly and too selectively on social and political matters. His reference earlier in his essay to J.H. Oldham's distinction presented at the Oxford Conference might profitably have been expanded and evaluated. Oldham distinguished between basic principles (love, justice, peace), middle axioms (goals and broad designs for a good society), and specific proposals (actual policies and legislation) (Schrotenboer, 1989:7). Our position is that the competence and calling of the institutional church are certainly to preach and teach the kingdom on the first, selectively and discerningly on the second, and probably never or almost never with regard to the third. Schrotenboer's essay, REC thinking, and Dutch GKN strategy could be clarified on the relationship of the kingdom of God and modern society by developing a paradigm such as Oldham's.

Peter Toon, a Reformed Anglican who has written much in the last thirty years on the kingdom from both a historical and a systematic theological perspective, includes a helpful chapter on the "Kingdom and Society" in his fine book, God's Kingdom for Today (1979). The biblical vision of the kingdom compels Christians to pray and to work for justice, he says. In this regard he acknowledges a "place, when it is done wisely, for public pronouncements by church synods and leaders on a moral issue - eg. racism, abortion, and euthanasia" (Toon, 1979:110). But nothing will be as effective in fostering the kingdom of God in modern society as 
Christians living the gospel and penetrating society with their daily practice of love, joy, peace, and righteousness. He warns against the danger of politicising the gospel, but also commends the Lausanne movement for addressing the social implications of the kingdom. Intuitively he operates with the institute-organism distinction as a guiding idea.

Calvin van Reken's brief, lucid essay on the matter in a recent issue of the Calvin Theological Journal (1999:198-202) operates with the distinction explicitly. He argues that the institutional church should speak emphatically on the biblical principles essential for achieving a healthy social order and on the social policy goals that harmonise with the kingdom of God. Just as emphatically he warns against the institutional church advocating specific policies in almost all cases. The only exceptions are when the policy is clearly immoral, when it reflects a clear consensus, and when it is done deliberatively by a major assembly. He warns that the organised church speaking out on social and political policies runs the risk of the church compromising its credibility by being mistaken and looking foolish, and the risk that this detracts from its primary calling. The church as organism, God's people deployed in society as individuals or in corporate association, are compelled by the kingdom to address the government, design and advocate improved social policies and programmes, and join organisations that hold the most promise of attaining the shape of human life that God intends.

We have spent considerable time reviewing a number of positions on how corporate modern discipleship comes to expression in the church. All these voices agree that the kingdom is the spiritual and moral reign of God in and through his people. All agree that Christians are to be under that rule of Christ, thus in the kingdom, in all aspects of human life. Several are much more explicit than others on the purpose and limitations of the institutional church because they operate with the distinction between church as institute and church as organism. Oldham and Van Reken and the Dutch GKN offer categories for classifying or segregating issues in the modern world on which the institutional church ought to announce the kingdom.

This evokes a final observation regarding the kingdom and modern society. It is that the task of the institutional church as the gathering of corporate modern disciples is to nurture the kingdom in Christians' lives, and through them in the modern world. This is its calling, its expertise, its privilege, and its source of blessing. It nurtures the kingdom in the modern world in the following ways: 
- By being true to its attributes and its marks.

- By creating and maintaining effective forms of kerygma, leiturgia, koinonia and diakonia.

- By equipping and motivating the saints for ministry.

- By illumining the modern world with the Word.

- By divesting itself of triumphalism and living as a serving, sometimes suffering, community.

- By its ministry of intercession.

- By reframing theological education to meet modern ecclesiastical realities.

Each of these responsibilities falls within the competence of the organised, institutional church. Each of them, if met faithfully and effectively, will result in hearts yielded to Jesus as Lord and King. Transformed hearts will produce transformed lives. Transformed lives will, individually and corporately, contribute toward the transformation of modern society. The kingdom comes in modern society when and how the Lord wants. But it only makes sense that it will come more quickly and more clearly through those within whom the kingdom is coming.

\section{Bibliography}

BERKHOF, Louis. 1951. The Kingdom of God: The Development of the Idea of the Kingdom, Especially Since the Eighteenth Century. Grand Rapids : Eerdmans.

NIEBUHR, H. Richard. 1951. Christ and Culture. New York : Harper \& Rowe.

RIDDERBOS, Herman. 1962. The Coming of the Kingdom. Trans. by H. de Jongste and edited by Raymond O. Zorn. Philadelphia : Presbyterian \& Reformed.

ROBERTSON, Archibald. 1901. Regnum Dei: Eight Lectures on the Kingdom of God in the History of Christian Thought. The Brampton Lectures, 1901. London : Methuen.

SCHROTENBOER, Paul G. 1989. Calling of the Church in a Changing World. Sioux Center, IA : Dordt College Press.

TOON, Peter. 1979. God's Kingdom for Today. Westchester, IL : Cornerstone Books. TUTU, Desmond. 1999. No Future Without Forgiveness. New York : Doubleday.

VAN REKEN, Calvin P. 1999. The Church's Role in Social Justice. Calvin Theological Journal, 34(1):198-202, April.

\section{Key words:}

discipleship; corporate institutional church kingdom and modern society modern society: features of

\section{Kernbegrippe:}

dissipelskap in groepsverband institusionele kerk koninkryk en hedendaagse samelewing samelewing; hedendaagse: kenmerke 


\title{
Response
}

\section{Response to J.A. de Jong - the kingdom of God and modern society}

\author{
P.J. Strauss \\ Department of Ecclesiology \\ University of the Free State \\ BLOEMFONTEIN \\ E-mail: pstrauss@shisas.com
}

\begin{abstract}
Response to J.A. de Jong - the kingdom of God and modern society

Three main points of critique can be levelled against the article of De Jong. The first one arises from his declared intention to let his ecclesiology determine his view on the kingdom of God. To my mind it would be more Biblical to let the cosmic rule of God and His redemptive work in Christ - in its totality - determine the kingdom. Secondly, why not use a Christian angle in analysing the problems of modern society? This could bring us nearer to the real problems. And then, thirdly, why not use an explicit Christian perspective as point of departure for treating the issues De Jong indicates as the issues of our time?
\end{abstract}

J.A. de Jong - standing in the long line of the Reformed tradition nevertheless also to some extent reflects the trends of his own times. De Jong is one of the modern disciples of Christ, for whom he is pleading in this lecture.

This fact is illustrated - on the one hand - in what he views as the features of modern Western society, but also - on the other hand - in his tendency to ask more questions than giving concrete answers on these features, features he describes as nine challenges or opportunities for the church in modern society. His notion to ask many questions is not cancelled by the fact that some of these questions are somewhat rhetoric of nature and are thus implying De Jong's views on the matter.

This observation clearly indicates that De Jong means what he states in his introduction that identifying the kingdom of God in modern society is a very complex undertaking. 


\section{Complexity of the kingdom or the sinful nature of man?}

From a Biblical point of view we confess that the all-embracing kingdom of God is a reality in society, be it on the basis of the "already" (indicative) and "not yet" (imperative) paradox we meet in the Old as well as in the New Testament. The question therefore remains whether the problem of the complexity of identifying the kingdom in modern society is due to the complexity of the kingdom itself, or to the sinful nature of man? To frame it somewhat differently: is God so complex in His ruling and in the revelation of His will that promoting the kingdom in modern society is a risky business, or are we, His disciples, lacking the insight and the courage to do so? Could it just be that Reformed Christians use the idea of the complexity of the issue to shy away from their responsibility to be the salt and the light in every aspect of life - with a somewhat post-modernistic emphasis on the pluralistic and complex nature of modern society, on the relativity of everything?

\section{Points of critique}

While I am in agreement with what De Jong states about the totality of the kingdom and the role of the organised church in modern society, I would like to utter three main points of critique.

\subsection{Not ecclesiology but the rule of God is the determining factor}

I experience a problem to understand why our ecclesiology should determine "to a significant degree" what we say and how we speak about the kingdom and modern society. If one interprets the kingdom in its cosmic sense as the point of departure, the church or, better, organised church, becomes one of the features of this kingdom. In this case not ecclesiology, but the rule of God - in His creation of all things and graceful redemption - is the determining factor. What is more, then the summary of the decalogue - or the 10 commandments itself - in Deut. 6:4 ff. etc. is a question of the first order while an ecclesiology, or the issue about the church, though overlapping with the decalogue to some extent, becomes a issue following this. Furthermore, from the viewpoint of the kingdom and God's cosmic reign, it is impossible to see how the church could be unqualifiedly named as the instrument of kingdom (cf. 2 and 3 in De Jong). Even if we attach to the church the meaning of body of Christ or believers. What is more, if we believe that our ecclesiology should determine our view on the kingdom and modern society because the church is the bearer of the Word of God in this dispensation, it should be said that from a Reformed perspective the church can never be the sole bearer of the Word. The Word can never be the possession of the church alone. Furthermore, to make the church the sole source for Scriptural guidelines in society, implies the dualism of nature and grace 
as it is found in scholastic circles. In this case the organised church becomes the mediator between the truth of God and society.

De Jong's emphasis on ecclesiology may be the reason why he tends to emphasise the role of the organised church in promoting the kingdom in modern society and only refers in vague terms to corporate actions by Christian believers in this society. With regard to what he says on this issue it must be stressed that it is not enough to say that the Word is not the task of the church only or that God sometimes speak to people in spite of the church. Although De Jong is an exponent of the concepts of special and common grace (revelation?) à la A. Kuyper, he does not integrate this with his view on the kingdom as a dynamic concept still revealing itself in every sphere of contemporary life.

Have we in the Reformed tradition silently or, in some cases more openly, abdicated from the truth that God should be served on His conditions in every aspect of life? Have we abandoned the idea of a Christian society because of secularisation or the misuse or wrong application of this in the past? Are we, after all, in agreement with Barth that the church can be the only Christian institution in society?

\subsection{Modern Western society is not analysed in terms of Biblical principles}

The second main point of critique is that De Jong does not try to analyse modern Western society in terms of Biblical principles, or better, a Christian world view. Why not try to identify the deeper motives of some feminists or gays in the process of social reconfiguration? Why not try to develop an attitude of how the children of the kingdom can come to terms with a religiously pluralistic society and, in this process, come to acceptable Christian guidelines for what the common good should be? And then, is the coming of the kingdom of God not the prime challenge for church and society? Is the secularised world determining the agenda for the kingdom or is there a possibility that it could be the other way round?

\subsection{No indications of concrete solutions}

My third point of critique stems from the fact that De Jong does not give an indication of concrete solutions or, at least, a Christian attitude to every modern challenge he identified for the church and the coming of the kingdom in modern society. Especially if he prefers - as is indeed the case - to use the kingdom in a redemptive, cosmic sense. 
For instance, to simply side with the poor without a meaningful and appropriate philosophy of how the problem came about and could be solved permanently or, to plea for a redistribution of wealth without trying to identify the underlying reasons for the situation in a balanced, comprehensive way, helps us very little. South Africa is one example to show that the elimination of a system which caused injustices, in this case apartheid, alone does not necessarily rectify the problem. In a postapartheid South Africa the gap between rich and poor, be it not along racial lines, is widening. Furthermore, the organised church at its very best can, as church, be little more than a facilitator or witness in helping to solve the problem of the needy and the poor.

And, while we are busy at a Reformed theological congress, are we not supposed to stress the will and some of the principles of the kingdom of God in its effect on modern society? 